\title{
Penerapan Model Pembelajaran Aptitude Treatment Interaction (ATI) untuk Meningkatkan Aktivitas dan Prestasi Belajar Siswa Kelas VIII-A SMPN 4 Kota Bima
}

\author{
Arif Rahman ${ }^{1}$ \\ ${ }^{1}$ STKIP Taman Siswa Bima \\ 1arifbima22@yahoo.com \\ ${ }^{*}$ Coresponding uthor
}

Artikel Info

Tanggal Publikasi

2019-06-30

Kata Kunci

Model Aptitude

Treatment Interaction

(ATI)

Aktivitas

Prestasi

\begin{abstract}
Abstrak
Penelitian ini bertujuan untuk meningkatkan aktivitas dan prestasi belajar siswa pada materi pokok lingkaran dengan menerapkan model pembelajaran Aptitude Treatment Interaction (ATI). Penelitian ini merupakan Penelitian Tindakan Kelas (PTK), yang dilaksanakan di kelas VIIIA SMPN 4 Kota Bima pada semester genap tahun pelajaran 2018/2019 dengan jumlah siswa 33 orang. Hasil penelitian ini menunjukkan terjadi peningkatan aktivitas dan prestasi belajar siswa yang di ditemukan pada setiap siklus. Peningkatan aktivitas siswa terlihat pada hasil observasi yang dilakukan observer pada siklus I dengan nilai rata-rata skor mencapai 1,67 dimana nilai ini termasuk dalam kriteria cukup aktif sedangkan prestasi belajar siswa terlihat pada ketuntasan belajar klasikal pada siklus I mencapai $78,78 \%$ dengan nilai rata-rata 73,93 . Oleh karena ketuntasan klasikal belum tercapai maka dilanjutkan ke siklus II dengan melakukan perbaikan-perbaikan pada siklus I. Dilihat dari hasil observasi aktivitas siswa pada siklus II dengan rata-rata skor mencapai 2,56 dimana nilai ini termasuk kriteria sangat aktif sedangkan ketuntasan belajar klasikal pada siklus II mencapai 90,90\% dengan nilai rata-rata 78,63. Ini artinya aktivitas dan prestasi belajar siswa mengalami peningkatan.
\end{abstract}

\section{PENDAHULUAN}

Belajar merupakan suatu proses perubahan yaitu perubahan tingkah laku sebagai hasil dari interaksi dengan lingkungannya dalam memenuhi kebutuhan hidupnya, (dalam Daryanto, 2010). Perubahan yang terjadi pada seseorang banyak sekali baik sifat maupun jenisnya karena itu sudah tentu tidak setiap perubahan dalam diri seseorang merupakan perubahan dalam arti belajar. Seseorang yang belajar akan menyadari terjadinya perubahan itu atau sekurang-kurangnya ia merasakan telah terjadi adanya suatu perubahan dalam dirinya. Menurut J.Brunner (dalam Daryanto, 2010) belajar tidak untuk mengubah tingkah laku tetapi untuk mengubah kurikulum sekolah menjadi sedemikian rupa sehingga siswa dapat belajar lebih banyak dan mudah mempelajari sesuatu yang dipelajari menjadi suatu keterampilan dan pengetahuan baru. Selain itu menurut R. Gagne (dalam Daryanto, 2010) memberikan definisi yaitu Belajar ialah suatu proses untuk memperoleh motivasi dalam pengetahuan, keterampilan, kebiasaan dan tingkah laku.

Berdasarkan observasi awal dan wawancara langsung peneliti dengan guru mata pelajaran matematika di SMPN 4 Kota Bima, ditemukan bahwa siswa kurang dilibatkan dalam kegiatan pembelajaran, siswa hanya duduk, diam dan mendengarkan apa yang disampaikan oleh guru. Hal ini juga di akui oleh guru, karena kecenderungannya dalam menggunakan metode ceramah sehingga partisipasi siswa dalam kegiatan pembelajaran masih kurang dan mengakibatkan rendahnya prestasi belajar siswa. Setelah peneliti mengidentifikasi penyebab masalah, maka peneliti mencoba menerapkan model pembelajaran Aptitude Treatment Interaction (ATI) dalam kegiatan pembelajaran.

Pembelajaran Aptitude Treatment Interaction (ATI) dimaksudkan adalah model ataupun produk desain pembelajaran yang secara sengaja didesain dan dikembangkan untuk menyesuaikan 
pembelajaran dengan karakteristik (aptitude) siswa dalam rangka mengoptimalkan prestasi akademik Cronback dan Snow (dalam Aziz, 2012). Menurut para ahli pendidikan (dalam Ismayani, 2011) diperoleh tiga makna esensial dari pembelajaran AptitudeTreatment Interaction (ATI) Pertama, model pembelajaran ini merupakan suatu konsep atau model yang berisikan sejumlah strategi pembelajaran (treatment) yang efektif digunakan untuk siswa tertentu sesuai dengan perbedaan kemampuan (aptitude) siswa. Kedua, sebagai sebuah kerangka teoritik model pembelajaran ini berasumsi bahwa optimalisasi prestasi akademik akan tercipta bila mana perlakuan-perlakuan (treatment) dalam pembelajaran disesuaikan sedemikian rupa dengan perbedaan kemampuan (aptitude) siswa. Ketiga, terdapat hubungan timbal balik antara prestasi akademik yang dicapai siswa dengan kondisi pengaturan pembelajaran di kelas.

Berdasarkan makna esensial yang telah dikemukakan, model pembelajaran Aptitude Treatment Interaction (ATI) bertujuan untuk menciptakan dan mengembangkan suatu model yang betul-betul peduli dan memperhatikan keterkaitan antara kemampuan (aptitude) seseorang dengan pengalaman belajar atau secara khas dengan strategi pembelajaran (treatment).

\section{METODE PENELITIAN}

Jenis penelitian yang digunakan dalam penelitian ini adalah penelitian tindakan kelas (PTK). Penelitian tindakan kelas (PTK) adalah penelitian tindakan yang dilaksanakan oleh guru di dalam kelas. PTK bertujuan untuk memperbaiki kinerjanya sebagai seorang guru, sehingga hasil belajar siswa menjadi meningkat. Ciri-ciri dari sebuah penelitian tindakan kelas (PTK) adalah Situasional, kontekstual, berskala kecil, praktis, terlokalisasi dan secara langsung, relevan dengan situasi nyata dalam dunia kerja (Arikunto, 2010).

Pendekatan yang dilakukan dalam penelitian ini adalah pendekatan Kuantitatif dan Kualitatif. Pendekatan kuantitatif dinamakan metode tradisional, karena metode ini sudah cukup lama digunakan sehingga sudah mentradisi sebagai metode penelitian (Sugiyono, 2012). Pendekatan kuantitatif diperoleh dari hasil evaluasi yang akan memberikan jawaban mengenai berhasil tidaknya proses pembelajaran, sedangkan pendekatan kualitatif sering disebut pendekatan penelitian naturalistik karena penelitiannya dilakukan pada kondisi yang alamiah, karena pada awalnya metode ini lebih banyak digunakan untuk penelitian bidang antropologi budaya; disebut sebagai metode kualitatif karena data yang terkumpul dan analisisnya lebih bersifat kualitatif (Sugiyono, 2012). Datanya diperoleh dari hasil observasi yang akan memberikan gambaran tentang kegiatan guru dan siswa terhadap proses pembelajaran.

Penelitian tindakan kelas yang digunakan adalah PTK model Kemmis dan McTaggart. Model Kemmis dan McTaggart pada hakekatnya berupa perangkat-perangkat atau untaian-untaian dengan satu perangkat terdiri dari beberapa komponen yaitu perencanaan tindakan, tahap pelaksanaan tindakan, tahap observasi, dan tahap refleksi, yang keseluruhannya merupakan satu siklus.

Model Kemmis dan McTaggart dapat digambarkan sebagai berikut.

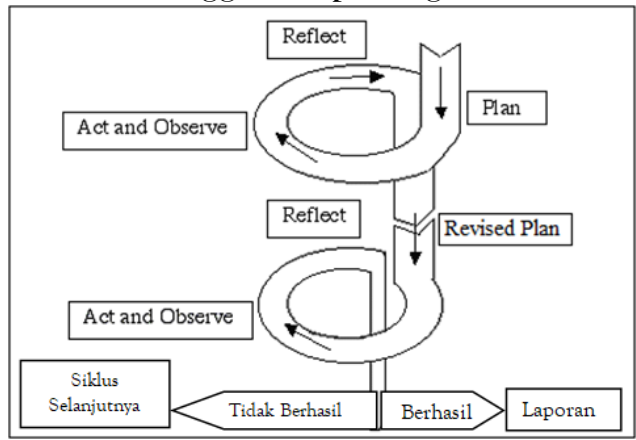

Gambar 2.1. Model PTK Kemmis dan McTaggart 
Dari skema PTK model Kemmis dan McTaggart tersebut dijelaskan bahwa langkah awal dari pelaksanaan tindakan kelas dimulai dari plan yang berarti perencanaan, dilanjutkan dengan act (tindakan) dan observe (pengamatan), dan reflect (refleksi). Jika setelah langkah-langkah tersebut dilakukan tetapi suatu penelitian tindakan kelas belum mencapai tujuan atau target yang diinginkan, maka akan dilaksanakan siklus berikutnya. Tahapan-tahapan yang dilakukan pada siklus berikutnya sama, hanya saja tindakannya diambil berdasarkan hasil refleksi siklus sebelumnya. Tapi jika tujuan penelitian sudah tercapai maka diakhiri dengan pembuatan laporan.

Data-data dalam penelitian ini di peroleh dengan menggunakan instrumen penelitian, berupa: Lembar Observasi, digunakan untuk mengetahui aktivitas belajar siswa dan guru dalam kegiatan belajar mengajar dengan mengamati dan mengisi lembar observasi sesuai dengan indikator aktivitas belajar. Observasi dilakukan pada saat kegiatan belajar mengajar antara siswa dan guru. Tes Hasil Belajar, digunakan untuk mengetahui sejauh mana tingkat kemampuan siswa dalam memahami materi yang telah diberikan sehingga di peroleh kesimpulan terhadap peningkatan hasil belajar siswa. Jenis tes yang digunakan adalah dalam bentuk uraian, setiap tes berisikan 5 soal. Tes ini memuat tentang materi pokok lingkaran yang akan diberikan pada akhir siklus, kemudian dianalisis secara kuantitatif.

Indikator keberhasilan penelitian tindakan kelas ini adalah peningkatan nilai rata-rata kelas dan ketuntasan belajar siswa setelah menerapkan model pembelajaran Aptitude Treatment Interaction(ATI) dan dibandingkan dengan tahun sebelumnya pada materi yang sama. Nilai rata-rata kelas dihitung dari skor rata-rata tiap siklus dengan rumus.

$$
\mathrm{M}=\frac{\sum_{i=i}^{n} X i}{n}
$$

Keterangan

$\mathrm{M}=$ rata-rata nilai siswa

$\mathrm{Xi}=$ nilai yang diperoleh siswa ke $\mathrm{i}, \mathrm{i}=1,2,3, \ldots . . \mathrm{n}$.

$\mathrm{n} \quad$ = banyak siswa yang mengikuti tes.

(dalam Sudjana, 2011)

Prestasi belajar siswa meningkat apabila terdapat peningkatan rata-rata dari skor sebelumnya. Dimana untuk mengetahui prestasi belajar siswa hasil tes dianalisis secara diskriptif dengan rumus berikut.

$$
\mathrm{KB}=\frac{T}{T t} x 100 \%
$$

Keterangan

$\mathrm{KB}=$ Ketuntasan belajar

$\mathrm{T}=$ Banyaknya siswa yang tuntas

$T_{t}=$ Banyaknya siswa yang hadir

(dalam Sudjana, 2011)

Ketuntasan belajar tercapai jika KB $\geq 85 \%$

Data aktivitas belajar siswa dianalisis dengan cara berikut.

\subsection{Menentukan skor aktivitas siswa secara klasikal untuk masing-masing deskriptor.}

- Skor 0 diberikan jika $X \leq 25 \%$

- Skor 1 diberikan jika $25 \%<\mathrm{X} \leq 50 \%$

- Skor 2 diberikan jika $50 \%<\mathrm{X} \leq 75 \%$

- Skor 3 diberikan jika X>75\%

Keterangan

$\mathrm{X}=$ Banyaknya siswa yang aktif melaksanakan aktivitas sesuai deskriptor. 
2.2 Analisis data aktivitas belajar siswa dengan menggunakan Mi (mean ideal) dan SDi (standar deviasi ideal).

$$
\begin{aligned}
& \mathrm{M}_{i}=\frac{1}{2} \text { (skor tertinggi }+ \text { skor terendah) } \\
& \mathrm{SD}_{i}=\frac{1}{3} \mathrm{M}_{i}
\end{aligned}
$$

\subsection{Menentukan kriteria aktivitas belajar siswa secara klasikal}

Untuk menentukan kriteria aktivitas belajar siswa secara klasikal digunakaan pedoman berikut.

Tabel 2.1. Pedoman penentuan kriteria aktivitas belajar siswa

\begin{tabular}{lll}
\hline Interval & Nilai & Kriteria \\
\hline $\mathrm{A} \geq \mathrm{MI}+1,5 \mathrm{SDI}$ & $\mathrm{A} \geq 2,25$ & Sangat aktif \\
\hline $\mathrm{MI}+0,5 \mathrm{SDI} \leq \mathrm{A}<\mathrm{MI}+1,5 \mathrm{SDI}$ & $1,75 \leq \mathrm{A}<2,25$ & Aktif \\
\hline $\mathrm{MI}-0,5 \mathrm{SDI} \leq \mathrm{A}<\mathrm{MI}+0,5 \mathrm{SDI}$ & $1,25 \leq \mathrm{A}<1,75$ & Cukup aktif \\
\hline $\mathrm{MI}-1,5 \mathrm{SDI} \leq \mathrm{A}<\mathrm{MI}-0,5 \mathrm{SDI}$ & $0,75 \leq \mathrm{A}<1,25$ & Kurang aktif \\
\hline $\mathrm{A}<\mathrm{MI}-1,5 \mathrm{SDI}$ & $\mathrm{A}<0,75$ & Sangat kurang aktif \\
\hline
\end{tabular}

(Keterangan: A adalah rata-rata skor aktivitas siswa)

Nurkencana (dalam Sudjana, 2011)

Penilaian kegiatan guru dilakukan melalui observasi langsung dimana guru yang sedang mengajar di observasi langsung oleh observer dan observer bersama guru di kelas, sedangkan data mengenai kegiatan guru diambil dengan chek list. Observer akan memberikan tanda check list pada "Ya" jika indikator dilaksanakan dan "Tidak" jika indikator tidak dilaksanakan. Data aktivitas guru dianalisis dengan rumus berikut.

$$
G=\frac{\Sigma y_{g}}{n} x 100 \%
$$

\section{Keterangan}

$$
\mathrm{G} \quad=\text { persentase aktivitas guru }
$$

$$
y_{g} \quad=\text { deskriptor yang muncul }
$$

$\mathrm{n} \quad=$ banyaknya deskriptor

Untuk menafsirkan hasil observasi digunakan kategori yang telah dimodifikasi berikut. Apabila persentase jumlah jawaban "Ya" (G) mencapai.

$80 \%<\mathrm{G} \leq 100 \%$, berarti Baik Sekali

$60 \%<\mathrm{G} \leq 80 \%$, berarti Baik

$40 \%<\mathrm{G} \leq 60 \%$, berarti Cukup Baik

$20 \%<\mathrm{G} \leq 40 \%$, berarti Kurang

$00 \%<\mathrm{G} \leq 20 \%$, berarti Kurang Sekali (Arikunto, 2010)

Adapun yang menjadi indikator keberhasilan dalam penelitian ini adalah pencapaian aktivitas dan prestasi belajar siswa dengan kriteria: Aktivitas belajar siswa dikatakan meningkat apabila terjadi peningkatan skor aktivitas belajar siswa pada setiap siklus dan minimal aktivitas belajar siswa kategori Aktif. Prestasi belajar siswa dikatakan meningkat jika ketuntasan klasikal pada tiap-tiap siklus meningkat, yaitu $\geq 85 \%$ siswa mandapatkan nilai $\geq 65$ dari hasil evaluasi belajar di akhir siklus.

\section{HASIL DAN PEMBAHASAN}

Penelitian tindakan kelas dilakukan sebagai upaya meningkatkan prestasi belajar matematika dan meningkatkan aktivitas siswa dalam kelas saat pembelajaran berlangsung khususnya untuk pokok 
bahasaan lingkaran. Penelitian ini berlangsung dalam dua siklus,dan subjek penelitian adalah siswa kelas VIII-A SMPN 4 Kota Bima.

\subsection{Siklus I}

\section{Data Hasil Observasi}

Pada kegiatan pembelajaran siklus 1 guru bidang studi dan teman sejawat yang bertindak sebagai observer dan mengisi lembar observasi untuk melihat sejauh mana pembelajaran yang berlangsung apakah sudah sesuai dengan skenario yang dibuat atau belum. Berikut adalah hasil yang diperoleh dari observasi kegiatan belajar mengajar dalam kelas.

Data hasil observasi siswa

Dari data hasil observasi aktivitas siswa siklus I yang dilakukan oleh observer terdapat rata-rata skor siklus I sama dengan 1,67 dimana nilai ini termasuk dalam kriteria cukup aktif. Hal ini menunjukkan kekurangan-kekurangan yang dilakukan oleh siswa, seperti: (1) Masuk kelas tidak tepat waktu, (2) Kurang mampu merespon pertanyaan yang diajukan guru, (3) Kurang mampu mengajukan pendapat atau sanggahan, (4) Kurangnya kerjasama antar anggota kelompok, (5) Kurang mampu membut kesimpulan hasil belajar.

Jadi hasil pengamatan dari siklus I skor aktivitas siswa dalam menerapkan pembelajaran Aptitude Treatment Interaction (ATI) termasuk dalam kriteria cukup aktif.

- Data hasil obervasi aktivitas guru

Dari data hasil observasi aktivitas guru siklus I terdapat skor total sama dengan 32 dengan persentase $88,88 \%$, dimana nilai ini termasuk dalam kriteria baik sekali. Tetapi pada saat melakukan tindakan masih ada kekurangan-kekurangan yang dilakukan oleh guru.

Berdasarkan hasil observasi yang dilakukan oleh observer menunjukkan kekurangankekurangan selama proses pembelajaran, seperti: (1) Guru masih kurang dalam pemberian apersepsi dan motivasi, (2) Guru belum optimal memberikan bimbingan kepada siswa untuk menarik kesimpulan dari hasil pembelajaran.

Jadi hasil pengamatan dari siklus I skor aktivitas guru dalam menerapkan pembelajaran Aptitude Treatment Interaction (ATI) berkriteria "Baik sekali”.

- Data Hasil Evaluasi

Setelah proses pembelajaran dilaksanakan pada siklus I selesai, maka dilakukan evaluasi yang diberikan dalam bentuk soal tes essay. Selanjutnya hasil analisis evaluasi siklus I dapat dilihat pada tabel berikut.

Tabel 3.1 Hasil Evaluasi Belajar Siswa Siklus I

\begin{tabular}{ll}
\hline Parameter & Nilai \\
\hline Nilai terendah & 50 \\
\hline Nilai tertinggi & 100 \\
\hline Nilai rata-rata & 73,93 \\
\hline Jumlah siswa yang ikut tes & 33 \\
\hline Jumlah siswa yang tuntas & 26 \\
\hline Persentasi ketuntasan & $78,78 \%$ \\
\hline
\end{tabular}

Dari data hasil evaluasi belajar siswa tersebut, persentase ketutasannya adalah 78,78\% dengan nilai rata-rata 73,93. Nilai ini masih belum memenuhi kriteria ketuntasan belajar klasikal yaitu $85 \%$. 
Berdasarkan hasil yang diperoleh dari siklus I maka diperlukan untuk melanjutkan penelitian ke siklus II dengan catatan perbaikan seperti: (1) Masuk kelas tepat waktu, (2) Guru harus bisa memberikan apersepsi dan motivasi untuk menumbuhkan minat belajar siswa, (3) Guru memberikan bimbingan kepada siswa tentang kerja dalam kelompok, (4) Guru mengarahkan agar siswa bisa meyimpulkan hasil belajar dengan bahasa sendiri, (5) Guru aktif mengatur dan memonitoring jalannya proses pembelajaran.

\subsection{Siklus II}

\section{Data Hasil Observasi}

Seperti pada halnya siklus I, kegiatan pembelajaran pada siklus II juga dilakukan observasi. Berikut adalah hasil observasi aktivitas siswa dan guru pada siklus II.

Data hasil observasi aktivitas siswa

Dari data hasil observasi aktivitas siswa siklus II yang dilakukan oleh observer terdapat rata-rata skor siklus II sama dengan 2,56 dimana nilai ini termasuk dalam kriteria sangat aktif. Hal ini menunjukkan bahwa rata-rata skor aktivitas siswa mengalami peningkatan dari 1,67 (cukup aktif) ke 2,56 (sangat aktif).

Data hasil observasi aktivitas guru

Dari data hasil observasi aktivitas guru siklus II terdapat skor total sama dengan 36 dengan persentase $100 \%$, dimana nilai ini termasuk dalam kriteria baik sekali. Hal ini menunjukkan bahwa ada peningkatan aktivitas guru pada siklus I $88,88 \%$ ke $100 \%$ pada siklus II dengan kriteria baik sekali.

- Data Hasil Evaluasi

Setelah proses pembelajaran dilaksanakan pada siklus II selesai, maka dilakukan evaluasi yang diberikan dalam bentuk soal tes essay. Selanjutnya hasil analisis evaluasi siklus II dapat dilihat pada tabel berikut.

Tabel 3. Hasil Evaluasi Belajar Siswa Siklus II

\begin{tabular}{ll}
\hline PARAMETER & NILAI \\
\hline Nilai terendah & 60 \\
\hline Nilai tertinggi & 100 \\
\hline Nilai rata-rata & 78,63 \\
\hline Jumlah siswa yang ikut tes & 33 \\
\hline Jumlah siswa yang tuntas & 30 \\
\hline Persentasi ketuntasan & $90,90 \%$ \\
\hline
\end{tabular}

Dari data hasil evaluasi belajar ini dapat dilihat bahwa siklus I persentase ketuntasan siswa $78,78 \%$ dan pada siklus II meningkat menjadi 90,90\%. Hal ini berarti bahwa hasil belajar siswa mengalami peningkatan.

Berdasarkan hasil observasi aktivitas siswa dan guru, serta hasil evaluasi belajar siswa pada siklus II diperoleh bahwa aktivitas siswa rata-rata skor 2,56 berkategori sangat aktif, dan hasil evaluasi belajar mencapai ketuntasan klasikal sebesar 90,90\%. Sedangkan aktivitas guru mendapatkan total skor 36 dengan kriteria baik sekali. Hal ini menunjukkan bahwa indikator penelitian telah tercapai, dan dilanjutkan ke tahap pelaporan.

Secara keseluruhan hasil penelitian ini menunjukkan bahwa pembelajaran Aptitude Treatment Interaction (ATI) pada materi pokok lingkaran dapat dikatakan berhasil. Hal ini dapat dilihat dari peningkatan kualitas proses dan prestasi belajar siswa yang telah memenuhi indikator 
pnelitian. Hal ini disebabkan pembelajaran Aptitude Treatment Interaction (ATI) yang menyesuaikan pembelajaran dengan karakteristik (aptitude) siswa, membantu menjadikan materi yang abstrak dan sulit mendapatkan contoh di lingkungan sekolah menjadi lebih konkret, siswa juga lebih mengenal dan terbiasa dengan kerja tim tutor sebaya. Pemberian perlakuan pada masing-masing kelompok membantu siswa yang lamban dalam memahami materi, serta pemberian rangkuman/kesimpulan pada akhir pelajaran membuat pelajaran lebih kuat dalam ingatan siswa.

Pengorganisasian pengajaran berdasarkan Model Aptitude Treatment Interaction (ATI) menyesuaikan siswa berdasakan kemampuan yang dmiliki oleh siswa, sehingga siswa yang kemampuannya rendah tidak merasa di anak tirikan dalam kelas, memberikan lingkungan belajar yang kondusif yang mendukung siswa mengungkap gagasan, saling menyimak satu sama lain, memberikan siswa kesempatan berfikir tentang pengalamannya, memberikan kesempatan bagi siswa untuk bertanya tanpa adanya kesenjangan antar siswa, ini dapat mendorong siswa berfikir kreatif dan imajinatif, sehingga pembelajaran menjadi menarik dan menyenangkan. Selain itu pembelajaran model Aptitude Treatment Interaction (ATI) ini dapat memberikan pengaruh positif dalam pembelajaran yaitu meningkatkan aktivitas dan prestasi belajar siswa.

\section{KESIMPULAN}

Berdasarkan data hasil penelitian maka dapat disimpulkan bahwa Model pembelajaran Aptitude Treatmennt Interaction (ATI) dapat meningkatkan aktivitas dan prestasi belajar siswa kelas VIII-A SMPN 4 Kota Bima pada materi pokok lingkaran tahun pelajaran 2018/2019. Peningkatan ini dapat dilihat dari ketuntasan belajar yang diperoleh pada siklus I yaitu sebesar 78,78\%. Hasil observasi aktivitas siswa sebesar 1,67 dengan kategori cukup aktif. Dan pada siklus II persentase ketuntasan belajar siswa meningkat menjadi 90,90\%. Hasil observasi aktivitas belajar siswa yaitu sebesar 2,56 dengan kategori sangat aktif. Ketercapaian ketuntasan belajar siswa pada siklus II tersebut menunjukkan bahwa melalui pembelajaran Aptitude Treatmennt Interaction (ATI) menyebabkan suasana belajar menjadi lebih hidup dengan partisipasi siswa dengan kegiatan pembelajaran yang dilakukannya, sehingga pembelajaran menjadi lebih menarik dan menyenangkan.

\section{Daftar Pustaka}

Arikunto, Suharsimi. 2010. Penelitian tindakan kelas. Jakarta: PT Bumi Aksara.

Arikunto, Suharsimi. 2010. Prosedur Penelitian Suatu Pendekatan Praktik Edisi Revisi 2010. Jakarta: Rineka Cipta.

Aziz, Fathul. 2012. Pengaruh Penerapan Model Pembelajaran Aptitude Treatment Interaction (ATI) Terhadap hasil belajar siswa materi pokok aljabar kelas VIII Mts. al-hamidy tahun pelajaran 2012/2013. Skripsi tidak diterbitkan. Mataram: IKIP MATARAM.

Daryanto. 2010. Psikologi belajar. Jakarta: Rhineka Cipta.

Ismayani, Iis., 2011. Penerapan Model Pembelajaran Aptitude Treatment Interaction (ATI) Dalam Upaya Meningkatkan Kemampuan Pemecahan Masalah Matematis dan Motivasi Belajar Siswa. Skripsi tidak diterbitkan. Bandung: Universitas Pendidikan Indonesia.

Nurul. 2010.Pembelajaran Elaborasi dalam meningkatkan prestasi belajar matematika siswa kelas VIII-A SMPN 4 praya barat daya tahun pelajaran 2010/2011. Skripsi tidak diterbitkan. Mataram: IAIN MATARAM.

Sudjana, N. 2011. Dasar-Dasar Proses Belajar Mengajar. Bandung: Sinar Baru Algensindo.

Sugiyono. 2012. Metode penelitian kuantitatif kualitatif dan R E D. Bandung: ALFABETA 